\title{
International Cooperation of the Pauls Stradiňš Museum of the History of Medicine
}

\author{
Juris Salaks \\ Pauls Stradiṇ̌ Museum of the History of Medicine, \\ Riga Stradinšs University, \\ Antonijas 1, \\ Riga LV-1360, Latvia \\ E-mail: juris.salaks@rsu.lv
}

\section{Introduction}

From the very beginning, the Pauls Stradinš Museum of the History of Medicine in Riga (museum), has been open to international contacts. In the past, partnerships with other Soviet republics were not seen as international cooperation. On the other hand, partnerships with institutions in the countries of the so-called Socialist partnership (East Germany, Poland, Bulgaria, Hungary, Czechoslovakia, etc.) were seen as international cooperation. Contacts with Western countries in the area of the history of medicine were the exclusive provenance of Moscow, and such efforts were not supported at the level of Soviet republics, apart from episodic visits by scholars and museum specialists from Socialist countries, visits to congresses as part of Soviet delegations.

The situation somewhat changed in the latter half of the 1980s, when the then Soviet Latvian health care minister Vilhelms Kaneps supported the conclusion of a real partnership agreement with the Institute of the History of Medicine of the Free University in West Berlin. In the late 1980s, the museum joined the European Association of Museums of the History of Medical Sciences (EAMHMS), which was possible only because of the aforementioned agreement. 


\section{Partnerships in the Western direction}

The international contacts of the museum changed very significantly after the restoration of Latvia's independence in 1991. The museum's contacts rapidly reached a new level of quality when it came to Western partners, and it also sought out new partners.

One of the first results of these international contacts involved research conducted by Juris Salaks to examine the medical work of the distinguished Baltic German physician Justus Christian von Loder (1753-1832). The research received much praise, and Mr Salaks was invited by Professor Rolf Winau, director of the Institute of the History of Medicine at the Free University in West Berlin, to defend his doctoral dissertation, The Work of Justus Christian von Loder in Establishing Medical Institutions in Russia, at the German university. The academic advisor was Professor Heinz Müller-Dietz, who was widely known both in the West and the East. Mr Salaks successfully defended his dissertation at the Free University in June 1991.

Another area of international contacts involved participation in international professional associations. This was also dictated by the fact that the Association of Baltic State Medical Historians was established at the museum on October 30, 1990 by the efforts of Professor Jānis Stradinš̌ and his colleagues from Estonia and Lithuania. The first chairman of the Baltic association was the director of museum, Docent Kārlis Ēriks Arons (1933-2005). He was also elected to the board of the EAMHMS, thus activating cooperation with other medical history museums in Europe. The first inter-congress seminar on the restoration of museum exhibits was held in Riga in 1993. Participants came mostly from Eastern European medical history museums, while lectors came from Western European universities and museums. A similar seminar was held in Riga in 1999. Even greater opportunities for international cooperation emerged after Latvia's accession to the European Union in 2004. In August 2006, the first EAMHMS congress ever to be held in Eastern Europe took place at the Pauls Stradinš Museum of the History of Medicine in Riga. It was the $13^{\text {th }}$ congress to be held, and it attracted more than 60 visitors and much praise from foreign colleagues. During the congress, the former president of EAMHMS Professor Christa Habrich (1940-2013) was awarded the P. Stradiņš Prize in recognition of her support to the museum in integration activities. 
At the same time, the museum has had successful examples of cooperation with museum exhibits. The museum deposited unique and large Soviet-era exhibits, including Vladimir Demikhov's (1916-1998) Two-Headed Dog, or the stuffed $\operatorname{dog}$ Chernushka, which was sent into space in March 1961. These exhibits were provided for large and much visited international exhibitions in Scandinavia and Germany. The biggest project—-the exhibition and conference "Ambermyths and science" with contributions from colleagues from Lithuania, Italy and Russia—was finalised in April 2014. During the first two decades of 2015 three international exhibitions dedicated to Andreas Vesalius anniversary were opened in the museum.

Of importance, too, in the establishment of contacts was the Institute of Medical History, which was founded in 1991 at the Latvian Academy of Medicine (now the Riga Stradiñ̌̌ University), because it had extensive international contacts in terms of the academic and scholarly aspects of the history of medicine.

Here it is worth mentioning the museum's compendium of scholarly papers, $I z$ istorii medicini ('From the history of medicine'), which has been published in Russian since 1957. In 1992, the museum and institute changed the journal and began to publish Acta medico-historica Rigensia with the help of an international group of editors. These changes were facilitated by a joint symposium organised by Latvia and West Berlin in 1990. This aspect of scholarly cooperation shrank over the course of time, and right now, when the tenth edition of the journal is being prepared, editors are thinking about restructuring the compendium in accordance with current academic trends in Europe so that the journal can be included in internationally recognised databases of scholarly journals.

In evaluating this so-called Western direction of the museum's partnerships, there were several objective circumstances which hindered the process after the restoration of Latvia's independence. Initially, the museum did not have a specific strategy, and its staff was driven by the natural desire to learn about the Western world. There was no partiality in choosing possible partners. The museum has traditionally had a German-speaking scholarly personnel, and the English-speaking younger generation, who was gradually becoming part of the process, was in demand in the West but could not evaluate and understand the possible priorities of the museum in terms of long-term partnerships.

It must also be noted that more successful international cooperation was hindered not so much by economic difficulties as by a post-Soviet inferiority complex and a low level of self-esteem. There were also biases related to idealisation of 
everything that came from the West. The development and improvement of communications were also hindered by a replacement in generations at the museum, as well as by the fact that many specialists left the museum for higherpaying jobs. The 2007 economic crisis, in turn, seriously reduced Latvia's and particularly the museum's development in the Western direction.

\section{Partnerships in the Eastern direction}

As the museum's partnerships with Western institutions became more intense, relationships with medical history institutions and museums in Russia and other former Soviet republics were interrupted for a period of time.

Colleagues from Latvia and the rest of the former USSR met at international events related to the history of medicine in "neutral" countries, but that did not happen in a planned way. This continued for approximately ten years. Only after Latvia's accession to the European Union in May 2004 did it become clear that international partnerships with the West were becoming irreversible, and so professional relations between medical historians in Russia and Latvia began to be reinstated as well.

Truly closer relations between medical historians and museums occurred only in 2009. Partial improvements in the political and economic relationship between Latvia and Russia, as well as the museum's accumulated experience in working with Western colleagues, led the museum to reassess its professional relationships in Russia.

An example of successful cooperation was the reconstruction of an exhibition related to cosmic biology and medicine that had been established at the museum during the Soviet era. Contacts were established between the museum and specialists at the Moscow Museum of Cosmonautics and the Institute of Bio-Medical Problems Institute Museum. The partnership resulted in a major international conference, held at the museum in the spring of 2011 in honour of the $50^{\text {th }}$ anniversary of the space flight of Yuri Gagarin. The tele-bridge was broadcast on the Latvian Television, and in this sense the museum was quicker than the great Euronews channel, which organised its first tele-bridge with the space station only six months later. 
Since 2010, these partnerships have become systematic and have taken on concrete forms, mostly in terms of methodological support, opportunities to work with Russian medical collections, as well as to integrate certain museums into the EAMHMS.

Today the museum is the European Union's leading partner in terms of medical history museums and associations and institutions of professional medical historians in Russia. The museum is advisor for the future national medical history museum in Russia. The partnership is also confirmed by two agreements that were concluded in 2012, and these have been implemented successfully. This suggests that the museum has managed to do thoughtful and purposeful work, not so much in terms of returning to a previous system, but instead in terms of doing specific work in the scientific and practical circulation and market of medical historians and museum specialists in the former Soviet Union.

\section{Future vision}

In marking out its future goals for international cooperation, the museum will have to classify existing contacts with the Western world so as to choose priorities in terms of cooperation and partners for various long-term projects, such as ERA.Net RUS Plus. It is clear that we must start putting together a specific offer that is focused on the Western market-lending exhibits and exhibitions, organising joint thematic and multi-sectoral exhibitions, granting access to the museum's unique collection of Soviet-era medical items, organising scientific tourism, and offering the museum's infrastructure to educational programmes and conferences.

One goal in terms of international cooperation is to preserve and develop partnerships with the East, expanding them in Russia and former Soviet republics, and positioning the museum as the most accessible one in geographical terms and the most appropriate one for post-Soviet mentality because of its thematically and chronologically diverse collections and experience. The museum must preserve its school of museum experience, offering Eastern colleagues a chance to learn about specific aspects of medical museum studies and to improve their qualifications. It is very important for the museum to strengthen its role as a mediator and advisor among Western and Eastern medical historians and museum specialists so as to ensure partnerships and mutual integration. 